\title{
Pola Tidur yang Buruk Meningkatkan Risiko Hipertensi
}

\author{
Poor Sleep Pattern Increases Risk of Hypertension \\ Santi Martini*, Shofa Roshifanni, Fanni Marzela \\ Universitas Airlangga \\ ("santi-m@fkm.unair.ac.id)
}

\begin{abstract}
ABSTRAK
Pola tidur yang buruk yaitu gangguan tidur, kualitas tidur yang buruk, dan durasi tidur yang pendek dapat meningkatkan risiko hipertensi. Hipertensi sendiri kini menjadi penyakit yang menduduki posisi tinggi yang sering dialami oleh masyarakat. Tujuan dari penelitian ini untuk mengetahui hubungan perilaku tidur yang buruk dapat meningkatkan risiko kejadian hipertensi. Penelitian ini merupakan penelitian observasional yang bersifat analitik dengan desain case control. Sampel dalam penelitian ini berjumlah 76 orang yang terdiri dari penderita hipertensi dan bukan penderita hipertensi pada Poli Umum Puskesmas Tanah Kalikedinding Surabaya. Teknik pengambilan sampel yang dilakukan menggunakan simple random sampling. Hasil penelitian menggunakan uji statistik regresi logistik menunjukkan ( $\mathrm{p}=0,000 ; \mathrm{OR}=9,022)$ artinya pola tidur memiliki pengaruh paling besar terhadap kejadian hipertensi dibandingkan dengan umur dan jenis kelamin. Kekuatan pengaruh pola tidur responden menunjukkan bahwa responden yang memiliki pola tidur yang buruk memiliki risiko 9,022 kali lebih besar terserang hipertensi dibandingkan dengan yang memiliki pola tidur baik. Pola tidur buruk antara lain gangguan tidur, kualitas tidur yang buruk, dan durasi tidur yang pendek. Rekomendasi yang diberikan kepada responden yang memiliki pola tidur buruk harus memperbaiki pola tidur dengan gaya hidup yang sehat yaitu tidur sesuai kebutuhan dan menjaga pikiran supaya tidak mengalami tekanan karena stres yang berlebih.
\end{abstract}

Kata kunci : Kualitas tidur, gangguan tidur, durasi tidur, hipertensi

\begin{abstract}
Poor sleep patterns of sleep disturbances, poor sleep quality, and short sleep duration may increase the risk of hypertension. Hypertension itself is now a disease that occupies a high position that is often experienced by the community. The purpose of this study was to determine the relationship of poor sleep patterns behavior increases the risk of hypertension. This research was an observational research that is analytic with case control design. The sample in this study amounted to 76 people consisting of patients with hypertension and non hypertension patients in Public Poly, Primary Haelth Care Tanah Kalikedinding Surabaya. The sampling technique was done using simple random sampling. The result of the research using logistic regression test showed ( $p 0,000 ;$ OR 9,022) that sleeping pattern has the greatest influence to the happening of hypertension compared to age and gender. The strength of the influence of sleep patterns of respondents showed that respondents who had a good pattern had a 9.022 times greater risk of not having hypertension than those who had poor sleep patterns. Poor sleep patterns include sleep disturbances, poor sleep quality, and short sleep duration. Recommendations given to respondents who have bad sleep patterns should improve sleep patterns with a healthy lifestyle that is sleeping as needed and keep the mind so as not to experience pressure because of excessive stress.
\end{abstract}

Keywords : Sleep quality, sleep disturbance, sleep duration, hypertension 


\section{PENDAHULUAN}

Tidur merupakan salah satu kebutuhan dasar manusia artinya secara alamiah manusia akan membutuhkan tidur sebagai kebutuhan setiap harinya. Tidur sebagai keadaan tidak sadar yang relatif lebih responsif terhadap rangsangan internal. Pada keadaan tidur kita dianggap mengalami keadaan pasif dan keadaan dorman dari kehidupan. ${ }^{1}$ Tidur terdiri dua tahapan yaitu $R a-$ pid Eye Movement (REM), yaitu active sleep dan Non-Rapid Eye Movement (NREM). NREM yaitu quiet sleep yang berfungsi untuk memperbaiki kembali organ-organ tubuh. Rapid Eye Movement akan mempengaruhi pembentukan hubungan baru pada korteks dan sistem neuroendokrin yang menuju otak. Non-Rapid Eye Movement akan mempengaruhi proses anabolik dan sintesis makromolekul Ribonukleic Acid (RNA). ${ }^{2}$

Pola tidur menjadi salah satu faktor risiko dari kejadian hipertensi. Pola tidur yang tidak adekuat dan kualitas tidur yang buruk dapat mengakibatkan gangguan keseimbangan fisiologis dan psikologis dalam diri seseorang. ${ }^{2}$ Selain itu, durasi tidur pendek dalam jangka waktu yang lama dapat menyebabkan hipertensi karena peningkatan tekanan darah 24 jam dan denyut jantung, peningkatan sistem saraf simpatik, dan peningkatan retensi garam. Selanjutnya akan menyebabkan adaptasi struktural sistem kardiovaskular sehingga tekanan darah menjadi tinggi. ${ }^{3}$

Kondisi yang dialami oleh individu dapat mempengaruhi pola tidurnya, beberapa faktor yang mempengaruhi pola tidur yaitu stres, lingkungan fisik, diet, obat-obatan, latihan fisik, penyakit, dan gaya hidup. Perubahan umur juga bisa berpengaruh terhadap pola tidur seseorang, sebenarnya yang terjadi bukan perubahan jumlah total tidur, tetapi kualitas tidur yang akan berubah, akan terjadi penurunan episode tidur REM yang akan cenderung memendek. ${ }^{4}$

Beberapa bukti yang diperoleh berdasarkan penelitian yang telah dilakukan oleh Javaheri, dkk pada tahun 2017 menyebutkan bahwa gangguan tidur, kualitas tidur yang buruk, dan durasi tidur yang pendek berkontribusi terhadap tekanan darah tinggi. ${ }^{5}$ Selain itu, berdasarkan beberapa penelitian yang dilakukan pada orang dewasa, kurang tidur sebagai salah satu faktor risiko dari hipertensi berupa waktu tidur yang lebih singkat dapat menye- babkan gangguan metabolisme dan endokrin yang dapat menyebabkan gangguan kardiovaskular. ${ }^{6}$

Tidur gelombang lambat yaitu kondisi tidur nyenyak (stadium 3 dan 4 atau N3 tidur) yang juga sering disebut "deep sleep" yang ditandai dengan "vagal tone" yaitu aktivitas pada saraf parasimpatik meningkat dan "sympathetic vagal" berkurang yaitu penurunan aktivitas pada saraf simpatik, dan akibatnya terjadi penurunan denyut jantung dan tekanan darah. Selain itu, penekanan tidur tidur nyenyak pada manusia memberikan dukungan untuk peran tidur nyenyak di homeostasis glukosa dan fluktuasi nokturnal tekanan darah. Hal tersebut menunjukkan proporsi tidur nyenyak yang rendah dikaitkan dengan kemungkinan kejadian hipertensi. ${ }^{5}$

Hubungan antara tidur dengan hipertensi terjadi akibat aktivitas simpatik pada pembuluh darah sehingga seseorang akan mengalami perubahan curah jantung yang tidak signifikan pada malam hari. Penurunan pada resistansi pembuluh darah perifer menyebabkan penurunan nokturnal normal pada tekanan arteri. Aktivitas saraf simpati saat tidur meningkat secara signifikan dan sangat bervariasi selama REM dibandingkan dengan waktu bangun tidur. Tekanan darah mendekati tingkat terjaga selama komponen pada tahap REM terlewati, dan sensitivitas baru meningkat selama tidur. Namun, kondisi demikian lebih efektif untuk meningkatkan penjagaan pada tekanan darah selama episode REM terjadi pada akhir periode tidur dari pada malam sebelumnya. Hal ini berkaitan dengan pola tidur. Tidur yang tidak normal terlibat dalam patogenensis prehypertension non dipping dan kemudian pada gangguan hipertensi pada kualitas tidur menyebabkan hipertensi. ${ }^{7}$ Beberapa penelitian yang telah dilakukan ada yang bersifat subjektif maupun objektif, tetapi keduanya memberikan hasil positif bahwa terdapat hubungan antara pola tidur dan risiko hipertensi. Penelitian yang dilakukan selama 20 tahun terakhir masih berfokus kepada faktor yang mungkin muncul karena hubungan secara langsung masih belum terlihat secara jelas. ${ }^{8}$ Penelitian ini bertujuan untuk mengetahui hubungan perilaku tidur yang buruk dapat meningkatkan risiko kejadian hipertensi. Hasil penelitian dapat menambah pengetahuan terkait perilaku tidur dan dapat diambil langkah pencegahan berdasarkan faktor tersebut. 


\section{BAHAN DAN METODE}

Penelitian dilakukan dengan menggunakan metode observasional yang bersifat analitik dengan desain case control yang dilakukan pada bulan Agustus 2015 sampai dengan Januari 2016. Sampel dalam penelitian ini berjumlah 76 orang yang terdiri dari 38 kasus dan 38 kontrol, yaitu penderita hipertensi dan bukan penderita hipertensi sebagai kontrol pada Poli Umum Puskesmas Tanah Kalikedinding Surabaya. Kriteria eksklusi yang ditetapkan untuk kontrol terhadap responden agar tidak terpengaruh oleh variabel lain, yaitu tidak menderita diabetes, tidak menderita penyakit ginjal kronis, memiliki tingkat sosial ekonomi yang sama, dan berada dalam satu etnis sehingga memiliki pola makan yang hampir sama. Pengambilan sampel dilakukan dengan menggunakan simple random sampling. Variabel yang digunakan adalah pola tidur yang diukur menggunakan kuesioner PSQI (The Pittsburgh Sleep Quality Index) dengan komponen penilaian meliputi durasi tidur, gangguan tidur, bantuan tidur (konsumsi obat tidur), dan penilaian subjektif kualitas tidur yang sudah sesuai dengan standar dan kriteria JNC VII untuk hipertensi yang dilihat dari kondisi tekanan darah dari catatan medik yang diperoleh di puskesmas serta riwayat minum obat anti hipertensi untuk mengontrol terjadinya recall bias. Variabel pendukung lainnya dalam penelitian ini mencakup umur dan jenis kelamin dari responden yang diperoleh dari wawancara kuesioner. Kemudian data yang diperoleh di analisis lebih lanjut menggunakan uji statistik regresi logistik multivariat. Penelitian ini telah disetujui oleh Komisi Etik Pene- litian Kesehatan Fakultas Kesehatan Masyarakat Universitas Airlangga.

\section{HASIL}

Karakteristik dari masing-masing individu menjadi faktor yang dapat berpengaruh terhadap kejadian hipertensi. Pengaruh tersebut bisa sebagai pendukung atau sebagai variabel pengganggu dalam penelitian. Pada penelitian ini melihat karakteristik individu, yaitu umur, jenis kelamin, dan pola tidur. Karakteristik responden yang ditampilkan pada Tabel 1, telah dibagi menjadi dua kelompok responden yaitu penderita dan bukan penderita hipertensi. Data yang ditampilkan menunjukkan bahwa responden penelitian paling banyak berada pada rentang umur 41-60 tahun yaitu sejumlah 21 orang pada penderita hipertensi dan 18 orang pada bukan penderita.

Menurut jenis kelamin dari responden yang ikut serta dalam penelitian perempuan mendominasi pada penderita hipertensi maupun bukan penderita hipertensi, jumlahnya masing-masing sejumlah 26 orang dan 27 orang. Sedangkan untuk variabel pola tidur sendiri jumlahnya hampir berimbang antara responden yang memiliki pola tidur baik dan buruk, yaitu masing-masing 37 dan 39 orang. Tabel 1 menunjukkan sebesar $76,3 \%$ responden yang mengalami hipertensi memiliki pola tidur yang buruk. Hal tersebut berbeda dengan kelompok yang tidak mengalami hipertensi, $73,7 \%$ memiliki pola tidur yang baik.

Selanjutnya data diolah lebih lanjut menggunakan uji statistik regresi logistik multivariat dengan menyertakan umur, jenis kelamin, dan pola

Tabel 1. Karakteristik Responden

\begin{tabular}{lcccc}
\hline \multirow{2}{*}{ Karakteristik } & \multicolumn{2}{c}{ Penderita Hipertensi } & \multicolumn{2}{c}{ Bukan Penderita Hipertensi } \\
\cline { 2 - 5 } & $\mathbf{n}$ & $\mathbf{\%}$ & $\mathbf{n}$ & $\mathbf{\%}$ \\
\hline Umur (tahun) & 3 & & & \\
$18-40$ & 21 & 7,89 & 18 & 18,4 \\
$41-60$ & 14 & 55,3 & 13 & 37,4 \\
61-88 & & 36,8 & & \\
Jenis Kelamin & 12 & 31,6 & 11 & 29 \\
$\quad$ Laki-laki & 26 & 68,4 & 27 & 71,1 \\
$\quad$ Perempuan & & & & 73,7 \\
Pola Tidur & 9 & 23,7 & 28 & 26,3 \\
$\quad$ Baik & 29 & 76,3 & 10 & \\
Buruk & & & &
\end{tabular}

Sumber : Data Primer, 2015 
Tabel 2. Jumlah Kebutuhan Tidur dalam Sehari Berdasarkan Umur

\begin{tabular}{lc}
\hline \multicolumn{1}{c}{ Umur } & Jumlah Kebutuhan Tidur \\
\hline $0-1$ bulan & $14-18 \mathrm{jam} /$ hari \\
1-8 bulan & $12-14 \mathrm{jam} /$ hari \\
18 bulan - 3 tahun & $11-12 \mathrm{jam} /$ hari \\
$3-6$ tahun & $11 \mathrm{jam} /$ hari \\
6- 12 tahun & $10 \mathrm{jam} /$ hari \\
12-18 tahun & $8,5 \mathrm{jam} /$ hari \\
18-40 tahun & $7-8 \mathrm{jam} /$ hari \\
$40-60$ tahun & $7 \mathrm{jam} /$ hari \\
60 tahun ke atas & $6 \mathrm{jam} /$ hari \\
\hline
\end{tabular}

Sumber : Data Primer, 2015

tidur terhadap kejadian hipertensi dari responden. Hasil akhir dari beberapa tahap analisis menunjukkan bahwa pola tidur menjadi variabel yang paling berpengaruh terhadap kejadian hipertensi dibandingkan dengan variabel lain. Hal tersebut dapat dilihat dari nilai signifikan pola tidur sebesar 0,000 yang ditunjukkan pada Tabel 3. Hasil perhitungan besar risiko diperoleh nilai $\operatorname{Exp}(\mathrm{B})$ atau disebut juga nilai OR sebesar 9,022 artinya risiko menderita hipertensi pada orang yang mempunyai pola tidur buruk 9,022 kali lebih besar dibandingkan orang yang mempunyai pola tidur baik. Seseorang yang pola tidur nya buruk mengalami risiko kejadian hipertensi yang sangat besar.

\section{PEMBAHASAN}

Durasi tidur akan berpengaruh terhadap kejadian hipertensi, hasil penelitian menunjukkan kondisi demikian. Menurut Calhoun \& Harding hubungan antara durasi tidur pendek dan hipertensi nampaknya paling signifikan selama usia paruh baya, durasi tidur yang objektif juga diukur dengan mengukur pewarnaan pergelangan tangan 3 hari dua kali antara tahun 2003 dan 2005, kualitas tidur, kejadian hipertensi 5 tahun, dan perubahan tekanan sistolik dan diastolik pada 578 orang Amerika berusia 33-45 tahun dan menunjukkan terjadinya insiden hipertensi $(\mathrm{OR}=1,37 ; 95 \% \mathrm{CI}=$ $1,05-1,78)$. Setiap jam tidur yang berkurang dikaitkan dengan kenaikan 37\% kemungkinan terjadinya insiden hipertensi. ${ }^{9}$

Berdasarkan pembagian jenis kelamin maka hasil penelitian menunjukkan bahawa perempuan memiliki risiko lebih tinggi terkait kejadian hipertensi. Penelitian yang dilakukan oleh Guo et al., di dalamnya menunjukkan perempuan memiliki risiko menderita hipertensi, terutama perempuan yang berada masa menopause. Kondisi tersebut karena akan terjadi kerentanan terhadap stres psikososial dan kekacauan hormonal yang dapat menyebakan hasil kesehatan yang buruk termasuk hipertensi. ${ }^{10}$ Perempuan sendiri umumnya mulai memasuki masa menopause pada umur 50 tahun. Kondisi tersebut dapat mengakibatkan gangguan pola tidur. Gangguan tersebut terjadi karena stres mengakibatkan seseorang mencoba terlalu keras untuk tidur, sering terbangun selama siklus tidur, atau terlalu banyak tidur, tidak hanya demikian apabila terus berlanjut maka akan menyebabkan kebiasaan tidur yang buruk. ${ }^{2}$ Penelitian yang dilakukan oleh Oktavia \& Martini juga menyebutkan bahwa orang yang memiliki tingkat stres berisiko mengalami hipertensi 9,07 kali lebih besar dibandingkan dengan yang tidak mengalami stres. ${ }^{11}$

Pola tidur yang dimiliki oleh responden penelitian juga berhubungan dengan kejadian hipertensi, responden yang memiliki pola tidur buruk lebih banyak mengalami hipertensi. Masalah pola tidur buruk yang paling sering dialami oleh individu berdasarkan penelitian yang dilakukan pada responden di pondok pesantren di Yogyakarta adalah durasi tidur kurang dari 7 jam sehari sebanyak 40 orang $(88,9 \%)$, terbangun tengah malam atau pagi hari sebanyak 29 orang $(64,4 \%)$, dan merasa terlalu kepanasan saat tidur di malam hari sebanyak 24 orang $(53,3 \%) .{ }^{12}$ Pola tidur dari setiap individu berbeda antara satu dengan yang lain, kondisi

Tabel 3. Model Akhir Regresi Logistik Multivariat terhadap Kejadian Hipertensi

\begin{tabular}{ccccccc}
\hline Variabel Independen & B & S.E & Wald & df & Sig. & $\operatorname{Exp(B)}$ \\
\hline Jenis kelamin & $-0,031$ & 0,586 & 0,003 & 1 & 0,957 & 0,969 \\
Umur & $-0,053$ & 0,578 & 0,009 & 1 & 0,926 & 0,948 \\
Pola tidur & 2,2 & 0,53 & 17,2 & 1 & 0 & 9,022 \\
Constant & $-1,065$ & 0,367 & 8,429 & 1 & 0.004 & 0,345 \\
\hline
\end{tabular}

Sumber : Data Primer, 2015 
tersebut dapat dipengaruhi oleh beberapa faktor. Salah satu faktor yang dapat berpengaruh adalah pertambahan umur yang selanjutnya akan berpengaruh pada penurunan kualitas tidur. ${ }^{4}$ Insomnia dan durasi tidur pendek dikaitkan dengan kejadian hipertensi, diabetes, dan peningkatan risiko untuk kejadian penyakt arteri koroner dan kongestif gagal jantung. ${ }^{13}$ Selain itu stres, lingkungan fisik, diet, obat-obatan, latihan fisik, penyakit, dan gaya hidup juga dapat berpengaruh terhadap pola tidur seseorang. ${ }^{2}$ Surabaya sebagai salah satu kota besar di Indonesia menjadi kota dengan tingkat keramaian yang tinggi karena jumlah penduduk yang tinggi sehingga terdapat berbagai kegiatan aktivitas selanjutnya kondisi tersebut memungkinkan seseorang yang tinggal mengalami stres yang lebih tinggi, suasana hunian yang terlalu padat juga akan mengakibatkan kebisingan dan udara tidak bisa bertukar dengan baik. ${ }^{2}$

Responden yang memiliki pola tidur yang baik cenderung terhindar dari hipertensi berbeda dengan kelompok yang memiliki pola tidur buruk. Kondisi tersebut sesuai pendapat yang berdasarkan hasil penelitiannya melaporkan bahwa risiko kejadian hipertensi meningkat secara signifikan pada individu yang didiagnosis dengan gangguan tidur dibandingkan individu tanpa gangguan yang berkaitan dengan tidur. Risiko yang lebih tinggi tersebut berlaku untuk semua kelompok umur dan jenis kelamin. ${ }^{8}$ Kualitas tidur yang buruk dapat mengubah hormon stres kortisol dan sistem saraf simpatik, sehingga dapat mengakibatkan terjadinya peningkatan tekanan darah. ${ }^{14,15}$

Menurut Guo et al., beberapa mekanisme patofisiologis potensial mendukung memang masuk akal karena bilogis durasi tidur yang singkat berhubungan dengan kejadian hipertensi. Hal tersebut berdasarkan penelitian yang dilakukan pada pekerja pria yang hasilnya menunjukkan bahwa kurang tidur menyebabkan peningkatan tekanan darah. Selanjutnya peningkatan tekanan darah disertai dengan disfungsi vaskular dan aktivitas peradangan. Selain itu, kondisi tersebut berkaitan dengan perubahan aktivitas saraf simpatik yang dibuktikan dengan pelepasan katekolamin yang meningkat dan penurunan denyut jantung. ${ }^{9}$ Kurang tidur yang berarti durasi tidur yang lebih pendek dapat meningkatkan beban hemodinamik 24 jam secara bertahap, meningkatkan aktivitas sistem saraf simpatis dan dalam paparan lebih lama akan menyebabkan adaptasi sistem kardiovaskular. ${ }^{15}$

Hubungan antara tidur dengan hipertensi terjadi akibat aktivitas simpatik pada pembuluh darah, seseorang akan mengalami perubahan curah jantung yang tidak signifikan di malam hari. Penurunan pada resistansi pembuluh darah perifer menyebabkan penurunan nokturnal normal pada tekanan arteri. Aktivitas simpati tidur meningkat secara signifikan dan sangat bervariasi selama pergerakan mata yang cepat (REM) dibandingkan dengan waktu bangun tidur. Tekanan darah mendekati tingkat terjaga selama komponen phasic REM, dan sensitivitas baru meningkat selama tidur. Namun, kondisi demikian lebih efektif untuk meningkatkan buffer pada tekanan darah selama episode REM terjadi pada akhir periode tidur dari pada malam sebelumnya. Hal ini berkaitan dengan pola tidur. Tidur yang tidak normal terlibat dalam patogenensis non-dipping pre-hipertensi dan kemudian pada gangguan hipertensi pada kualitas tidur menyebabkan hipertensi. ${ }^{7}$

Penelitian yang dilakukan di China memperoleh kesimpulan bahwa berdasarkan hasil kuesioner PSQI yang dikaitkan dengan peningkatan kemungkinan hipertensi pada populasi penelitian maka seseorang yang memiliki pola tidur yang buruk seperti durasi tidur yang pendek, kualitas tidur yang buruk, latensi tidur yang berkepanjangan, dan gangguan tidur mengalami peningkatan kemungkinan hipertensi. Pola tidur yang buruk akan mengakibatkan aktivasi sistem saraf simpatik yang lebih tinggi. ${ }^{7}$ Pendapat tersebut juga sesuai dengan pendapat yang berdasarkan hasil penelitian yang dilakukan oleh Setiawan pada tahun 2016 yang menyatakan bahwa gangguan pola tidur dikhawatirkan akan mempengaruhi vitalitas terutama terhadap tekanan darah pada orang yang mengalami gangguan pola tidur, serta pendapat Moi et al., yaitu gangguan tidur kurang maka tekanan darah normal, sedangkan gangguan tidur buruk akan mengakibatkan tekanan darah rendah ataupun tinggi..$^{17,18}$

Risiko hipertensi karena pola tidur yang buruk juga didukung dengan penelitian yang pernah dilakukan pada sampel yang mewakili $8 \%$ sampai $10 \%$ populasi di AS, hasilnya $50 \%$ penderita insomnia kronis dan lebih dari $20 \%$ subyek dengan 
durasi tidur yang dimiliki kurang, yaitu $<5$ jam dengan individu yang memiliki tidur yang kurang berisiko secara klinis dan signifikan secara statistik untuk hipertensi dan kemungkinan gangguan kardiovaskular lainnya. ${ }^{19}$ Padahal setiap individu memiliki kebutuhan tidur per hari berdasarkan umur. Orang yang berada pada masa dewasa memiliki kebutuhan tidur antara 7-8 jam per hari yang sangat disarankan untuk diterapkan dengan untuk hidup sehat. ${ }^{20}$

Pemenuhan kebutuhan istirahat tidur memiliki hubungan dengan kejadian hipertensi, hal ini merupakan kesimpulan dari penelitian yang dilakukan oleh Winarni \& Hartanto pada tahun 2016. ${ }^{21}$ Kondisi demikian terjadi karena tidur dapat memberikan pengaruh terhadap sistem saraf dan organ tubuh manusia yang lain secara fisiologis. Beberapa komponen dalam tubuh termasuk sistem saraf yang telah digunakan untuk melakukan berbagai aktivitas, untuk memulihkan maka diperlukan tidur sebagai sarana istirahat. Tidur juga berperan dalam proses sintesis protein, secara pskilogis sendiri, tidur juga penting karena seseorang yang memiliki jumlah jam tidur yang tidak cukup maka akan cenderung menjadi mudah marah secara emosional, konsentrasinya buruk, serta mengalami kesulitan dalam membuat keputusan.

\section{KESIMPULAN DAN SARAN}

Kesimpulan dari penelitian adalah pola tidur memiliki pengaruh yang paling tinggi terhadap kejadian hipertensi dibandingkan dengan varibel lain yaitu umur dan jenis kelamin. Tidak hanya itu risiko menderita hipertensi pada orang yang mempunyai pola tidur buruk 9,022 kali lebih besar dibandingkan orang yang mempunyai pola tidur baik. Perlu dilakukan upaya pencegahan yang dapat dilakukan oleh masyarakat, yaitu dengan merubah pola tidur sesuai dengan kebutuhan menurut kriteria umur serta menjaga pikiran untuk tidak mengalami tekanan stres yang berlebih.

\section{DAFTAR PUSTAKA}

1. Arifin AR, Burhan E. Fisiologi Tidur dan Pernapasan. J Respiologi. 2010;1-12.

2. Potter P, Perry A. Fundamental Keperawatan. Jakarta: EGC; 2006.

3. Gangwisch JE, Heymsfield SB, Boden-Albala B, Buijs RM, Kreier F, Pickering TG, et al. Short Sleep Duration as a Risk Factor for Hypertension: Analyses of the First National Health and Nutrition Examination Survey. Hypertension. 2006;47(5):833-9.

4. Marlina, Ns OM. Faktor - Faktor yang Mempengaruhi Tidur pada Lanjut Usia di Desa Meunasah Balek Kecamatan Kota Meureudu Kabupaten Pidie Jaya. J Ilmu Keperawatan dan Kebidanan. 2010;1(4).

5. Javaheri S, Zhao YY, Punjabi NM, Quan SF, Gottlieb DJ, Redline S. Slow-Wave Sleep Is Associated with Incident Hypertension: The Sleep Heart Health Study. Sleep. 2018 Jan 1;41(1). DOI:10.1093/sleep/zsx179.

6. Javaheri S, Storfer-Isser A, Rosen C. Sleep Quality and Elevated Blood Pressure in Adolescents. Circulation. 2008;118(10):1034-40.

7. Liu R-Q, Qian Z, Trevathan E, Chang J-J, Zelicoff A, Hao Y-T, et al. Poor Sleep Quality Associated with High Risk of Hypertension and Elevated Blood Pressure in China: Results from a Large Population-Based Study. Hypertens Res. Nature Publishing Group; 2016;39(1):54-9.

8. Fobian AD, Elliott L, Louie T. A Systematic Review of Sleep, Hypertension, and Cardiovascular Risk in Children and Adolescents. Curr Hypertens Rep. Current Hypertension Reports; 2018;20(42):1-11.

9. Calhoun DA, Harding SM. Sleep and hypertension. Chest. 2010;138(2):434-43.

10. Guo J, Fei Y, Li J, Zhang L, Luo Q, Chen G. Gender and Age Specific Associations between Sleep Duration and Prevalent Hypertension in Middle-Aged and Elderly Chinese: A Cross-Sectional Study from CHARLS 2011-2012. BMJ Open. 2016;6(9).

11. Oktavia F, Martini S. Besar Risiko Kejadian Hipertensi Berdasarkan Faktor Perilaku pada Tentara Nasional Indonesia (TNI). Media Kesehatan Masyarakat Indonesia. 2016;12(3):127-36.

12. Rahmadani O, Kalbuningrum DCA. Naskah publikasi. Hubungan antara Pola Tidur terhadap Tekanan Darah pada Remaja SMA di Pondok Pesantren Al-Munawwir Krapyak Yogyakarta. 2017;1-23.

13. Bertisch S., Pollock BD, Mittleman MA, Buysse DJ, Bazzano LA, Gottlieb DJ, et al. 
Insomnia with Objective Short Sleep Duration and Risk of Incident Cardiovascular Disease: Sleep Heart Health Study. Sleep. 2015;38(July):1-9.

14. Amanda H, Prastiwi S, Sutriningsih A. Hubungan Kualitas Tidur dengan Tingkat Kekambuhan Hipertensi pada Lansia di Kelurahan Tlogomas Kota Malang. Nurs News (Meriden). 2017;2(3):437-47.

15. Mohani VS, Nurhayati T, Sari DM. Sleeping Quality Does NotAffect Blood Pressure among Elderly in Tresna Werdha Nursing Home City of Bandung. J Med Heal. 2018;2(2):722-9.

16. Luthfi M, Azmi S, Erkadus. Artikel Penelitian Hubungan Kualitas Tidur dengan Tekanan Darah pada Pelajar Kelas 2 SMA Negeri 10 Padang. J Kesehat Andalas. 2017;6(2):318-23.

17. Setiawan D. Kandang Kecamatan KedungKandang Kota Malang (The Correlation between Sleep Patterns and Blood Pressure In
People With the Age 30-60 Years in RT 05 RW 02 Kedung-Kandang). J Nurs Care Biomol. 2016;1(2):64-9.

18. Moi MA, Dyah W, Ani S. Hubungan Gangguan Tidur dengan Tekanan Darah pada Lansia. Nurs News (Meriden). 2017;2(2):124-31.

19. Vgontzas AN, Liao D, Bixler EO, Chrousos GP, Vela-Bueno A. Insomnia with Objective Short Sleep Duration is Associated with a High Risk for Hypertension. Sleep. 2009;32(4):491-7.

20. Kemenkes RI. Promosi Kesehatan Departemen Kesehatan Republik Indonesia [Internet]. Jakarta : Kemenkes RI; 2016.

21. Winarni W, Hartanto PY. Hubungan antara Pemenuhan Kebutuhan Istirahat Tidur dengan Kejadian Hipertensi pada Masyarakat di Dusun Celep Kidul Kelurahan Dagen Kecamatan Jaten Karanganyar. 2016;4(2):197-203. 